\title{
Notes on the sand fly fauna (Diptera: Psychodidae) in a region of Brazil
}

\author{
Notas sobre a fauna de flebotomíneos (Diptera: Psychodidae) em uma região do Brasil \\ Notas sobre la fauna de flebótomos (Diptera: Psychodidae) en una región de Brasil
}

Received: 10/28/2021 | Reviewed: 11/07/2021 | Accept: 11/10/2021| Published: 11/14/2021

Paula Fassicolo Variza

ORCID: https://orcid.org/0000-0001-9677-4438

Universidade do Sul de Santa Catarina, Brasil

E-mail:paula_fas@hotmail.com

Thiago Nunes Pereira

ORCID: https://orcid.org/0000-0003-4038-7337 Instituto René Rachou, FioCruz, Brasil

E-mail: thiagonunes_@hotmail.com

Joice Guilherme de Oliveira

ORCID: https://orcid.org/0000-0001-7200-8720

Universidade do Sul de Santa Catarina, Brasil

E-mail: joice_o@hotmail.com

Millena Fernandes

ORCID: https://orcid.org/0000-0002-4641-1417

Universidade do Sul de Santa Catarina, Brasil

E-mail: millena.bn.f@gmail.com

Daniel Moreira de Avelar

ORCID: https://orcid.org/0000-0001-7907-7913 Instituto René Rachou, FioCruz, Brasil

E-mail: daniel.avelar@ fiocruz.br

Tarcísio de Freitas Milagres

ORCID: https://orcid.org/0000-0002-7397-1612

Universidade Federal do Rio Grande do Sul, Brasil

E-mail: tarcisiodefreitasmilagres@gmail.com

Wellington Junior da Silva

ORCID: https://orcid.org/0000-0001-9377-3800

Universidade Federal do Rio Grande do Sul, Brasil

E-mail: wellingtonbxo@ hotmail.com

Diogo Tavares Cardoso

ORCID: https://orcid.org/0000-0002-7375-4837

Universidade Federal de Minas Gerais, Brasil E-mail: diogo.tavares0@yahoo.com.br

Onilda Santos da Silva

ORCID: https://orcid.org/0000-0003-4806-8285

Universidade Federal do Rio Grande do Sul, Brasil

E-mail: onilda.santos@gmail.com

Célia Maria Ferreira Gontijo

ORCID: https://orcid.org/0000-0002-7034-535X Instituto René Rachou, FioCruz, Brasil

E-mail: celia.gontijo@fiocruz.br

Josiane Somariva Prophiro

ORCID: https://orcid.org/0000-0002-1840-1115

Universidade do Sul de Santa Catarina, Brasil E-mail: josiane.prophiro@hotmail.com

\begin{abstract}
The family Psychodidae has a cosmopolitan distribution with members that occur in many habitats, mainly in humid environments, and is most diverse in the tropics. Subfamilies Sycoracinae and Phlebotominae have females with hematophagous habits and the latter studied more due to medical and veterinary interest, since it includes species that can transmit diseases to animals and humans. The knowledge about the sand fly fauna in a region is extremely important for adequate monitoring and control measures for leishmaniasis. Thus, the objective of this study was to characterize Psychodidae fauna in relation to richness, abundance and molecular identification of Leishmania spp. in sand flies in southern Santa Catarina, Brazil. The ollections were carried out between 2015 and 2016 in three cities in Santa Catarina, Brazil. Samples were taken near feeding places for domestic animals, urban forest and peridomicile areas. The insects were identified and female sand flies were submitted to molecular analysis to detect the presence of Leishmania spp.. A total of 4,200 insects were collected, 4,193 from the Sycoracinae subfamily and 7 Phlebotominae
\end{abstract}


from the Nyssomyia neivai and Pintomyia fisheri species. Of the studied municipalities, sandflies were registered in Tubarão and Imaruí and the most frequent habitat was the peridomicile areas. No samples were positive for Leishmania spp. In conclusion, the work highlights the presence of two species of sandflies, which were recorded for the first time in southern Santa Catarina.

Keywords: Psychodidae; Sycoracinae; Phlebotominae; Sand fly; Leishmaniasis.

\begin{abstract}
Resumo
A família Psychodidae possui distribuição cosmopolita com membros que ocorrem em diversos habitats, principalmente em ambientes úmidos, sendo mais diversa nos trópicos. As subfamílias Sycoracinae e Phlebotominae apresentam fêmeas com hábitos hematófagos, sendo esta última estudada mais por interesse médico e veterinário, pois inclui espécies que podem transmitir doenças para animais e humanos. O conhecimento da fauna de flebotomíneos em uma região é de extrema importância para o adequado monitoramento e controle da leishmaniose. Assim, o objetivo deste estudo foi caracterizar a fauna de Psychodidae em relação à riqueza, abundância e identificação molecular de Leishmania spp. em flebotomíneos no sul de Santa Catarina, Brasil. As coletas foram feitas entre 2015 a 2016 em três cidades catarinenses. As amostras foram coletadas próximo a locais de alimentação de animais domésticos, floresta urbana e áreas de peridomicílio. Os insetos foram identificados e flebotomíneos fêmeas foram submetidos a análises moleculares para detecção de Leishmania spp. Foram coletados 4.200 insetos, sendo 4.193 espécimes da subfamília Sycoracinae e 7 Phlebotominae das espécies Nyssomyia neivai e Pintomyia fisheri. Dos municípios estudados, os flebotomíneos foram registrados em Tubarão e Imaruí e o habitat mais frequente foram as áreas de peridomicílio. Nenhuma amostra foi positiva para Leishmania spp. Em conclusão, o trabalho destaca a presença de duas espécies de flebotomíneos, que foram registradas pela primeira vez no sul de Santa Catarina.
\end{abstract}

Palavras-chave: Psychodidae; Sycoracinae; Phlebotominae; Flebotomíneo; Leishmanioses.

\title{
Resumen
}

La familia Psychodidae tiene una distribución cosmopolita con miembros que se encuentran en diferentes hábitats, principalmente en ambientes húmedos, siendo más diversos en los trópicos. Las subfamilias Sycoracinae y Phlebotominae tienen hembras con hábitos hematófagos, siendo esta última más estudiada por interés médico y veterinario, ya que incluye especies que pueden transmitir enfermedades a animales y humanos. El conocimiento de la fauna de flebótomos en una región es extremadamente importante para el seguimiento y control adecuados de la leishmaniasis. Así, el objetivo de este estudio fue caracterizar la fauna de Psychodidae en relación a la riqueza, abundancia e identificación molecular de Leishmania spp. en flebótomos en el sur de Santa Catarina, Brasil. Las recolecciones se realizaron entre 2015 y 2016 en tres ciudades de Santa Catarina. Las muestras se recolectaron cerca de sitios de alimentación de animales domésticos, bosques urbanos y áreas de peridomicilo. Se identificaron insectos y se sometieron a análisis moleculares hembras de flebótomos para detectar Leishmania spp. Se recolectaron un total de 4.200 insectos, 4.193 de la subfamilia Sycoracinae y 7 Phlebotominae de las especies Nyssomyia neivai y Pintomyia fisheri. De los municipios estudiados, se registraron flebótomos en Tubarão e Imaruí y el hábitat más frecuente fue el peridomicilio. Ninguna muestra fue positiva para Leishmania spp. En conclusión, el trabajo destaca la presencia de dos especies de flebótomos, que se registraron por primera vez en el sur de Santa Catarina.

Palabras clave: Psychodidae; Sycoracinae; Phlebotominae; Flebotomina; Leishmaniasis.

\section{Introduction}

The family Psychodidae comprises small Diptera that are characterized mainly by having a body covered with bristles (Sherlock, 2003). It has a cosmopolitan distribution with members that occur in many habitats, mainly in humid environments, and is most diverse in the tropics. The family has more than 3,000 described species subdivided into 6 subfamilies: Bruchomyiinae, Psychodinae, Trichomyiinae, Sycoracinae, Phlebotominae, and Horaiellinae (the last occurs only in East Asia) (Bejarano \& Estrada, 2016; Pape et al., 2011).

Subfamilies Sycoracinae and Phlebotominae have females with hematophagous habits and the latter studied more due to medical and veterinary interest, since it includes species that can transmit different diseases (e.g., leishmaniasis) to animals and humans (Guimarães et al., 2014; Pape et al., 2011; Sherlock, 2003). According to Young \& Duncan (1994) (Young \& Duncan, 1994), the Leishmania spp. vectors in the Americas belong to Lutzomyia, but in a new classification by Galati (2003) (Galati, 2003) this genus was divided in to many genera, especially Lutzomyia, Migonemyia, Pintomyia, Bichronomyia, Psychodopygus, Nyssomyia and Trichophoromyia (Galati, 2003; Young \& Duncan, 1994). In addition, the largest number of species of sandflies is found in the Americas, with Brazil being the country with the greatest diversity of species (Galati, 2003). 
Leishmaniasis is caused by an infection with Leishmania spp. and is among the most neglected diseases in the world, affecting poor populations, especially in developing countries. Leishmaniasis can occur in cutaneous and mucocutaneous (American Tegumentary Leishmaniasis) and visceral (Visceral Leishmaniasis) forms, depending on the parasitic species involved in the infection. Visceral leishmaniasis is the most worrisome form of the disease, and when not diagnosed and treated early, the mortality rate can reach 10\% (Alves, 2009; de Brito et al., 2014; World Health Organization, 2010). According to the World Health Organization (WHO) (World Health Organization, 2010), almost two million new cases of leishmaniasis are reported world wide each year

In Brazil, at 2015, 20.975 LTA cases (Ministério da Saúde, 2020a) and 3.558 LV cases were confirmed (Ministério da Saúde, 2020c). This country, which concentrates 95\% of cases of VL in the Americas (Alvar et al., 2012), had the southern region considered free of the disease until 2009, but the number of cases has grown in recent years (Deboni et al., 2011). In Santa Catarina State, between 2011 and 2019, 14 LV cases were confirmed (Ministério da Saúde, 2020d) and, between 2010 and 2019, 193 LTA cases were confirmed (Ministério da Saúde, 2020b). At 2012 the State of Santa Catarina, reported the first autochthone cases of canine visceral leishmaniasis in state's capital (Figueiredo et al., 2012). Further, there are many problems with mapping the leishmaniasis cases as there are a large number of unreported cases (Gontijo \& Melo, 2004). Thus, were reported revealed a new endemic area in the northeastern part of the state, with two Leishmania species present, whereas in the southern part the infection cases are predominantly imported, except for three Leishmania (Leishmania) amazonensis cases (Marlow et al., 2013).

The sand fly habitat in an area may be influenced by several factors, such as food and the rainfall index. With increasing deforestation and urbanization, these insects are also developing in peri-urban and urban areas, indicating their ability to inhabit anthropic environments (Feitosa \& Castellón, 2006; Ramos et al., 2014; Souza et al., 2010). Thus, knowing the insect fauna is important so it can be compared with other regions to establish an epidemiological profile, since each region, depending on its location, temperature and other variables, may have different species (in quantity and variety).

Therefore, knowledge about the sand fly fauna in a region is extremely important for adequate monitoring and control measures for leishmaniasis. In addition, the sand fly fauna in Santa Catarina is poorly described, with few species listed for the state, and until now, no study had been carried out in the southern region. Thus, the objective of this study was to characterize Psychodidae fauna in relation to richness, abundance and molecular identification of Leishmania spp. in sand flies of the subfamily Phlebotominae in southern Santa Catarina, Brazil.

\section{Material and Methods}

\subsection{Collection and identification}

The study was cross-sectional with a quantitative approach and the collections were made out in three cities in Santa Catarina, Brazil: Criciúma (latitude 28 40'42" south and longitude 49 $22^{\prime} 13^{\prime \prime}$ west), Tubarão (latitude $28^{\circ} 28^{\prime} 00^{\prime \prime}$ south and

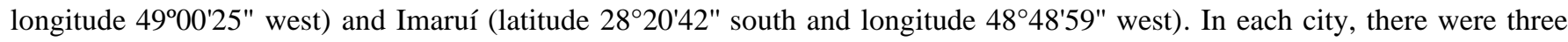
collection sites: (A) peridomicile area; (B) urban forest; and (C) near feeding places for domestic animals (chickens, pigs, dogs and cattle).

The geolocations of the different points are in Table 1. The insects were captured using CDC luminous traps from April 2015 to March 2016. The collections were made monthly for approximately 12 hours ( 18:00 pm to 06:00 am) per sampling period. The collected insects were screened, separating, and those with a morphology similar to Psychodidae were further identified. Identifications were made using keys by Galati (2003) (Galati, 2003) and Sycoracinae was identified to subfamily. All insects selected were stored in $70 \%$ alcohol. 
Table 1. Geolocation collection points.

\begin{tabular}{cccc}
\hline Locality & Point A & Point B & Point C \\
\hline \multirow{2}{*}{ Criciúma } & $-28.6973466,-49.3681427$ & $-28.7207446,-$ & $-28.7049809,-$ \\
& & 49.3697917 & 49.3779168 \\
\hline Tubarão & $-28.496528,-49.025939$ & $-28.477459,-49.023666$ & $-28.520065,-49.017660$ \\
\hline Imaruí & $-28.300931,-48.761454$ & $-28.303216,-48.762705$ & $-28.303346,-48.761259$ \\
\hline \multicolumn{4}{c}{ Source: Authors. }
\end{tabular}

\subsection{Sand fly DNA extraction}

DNA extraction was performed with a Gentra Puregene ${ }^{\circledR}$ QIAGEN tissue kit following the protocol modified by Quaresma et al (2011) (Quaresma et al., 2011): females were macerated in 100 $\mu 1$ of cell lysis solution and $1 \mu$ l of proteinase $\mathrm{K}$ was added to the mixture. The solution was homogenized by tube inversion and incubated at $55^{\circ} \mathrm{C}$ overnight. After incubation, $1 \mu$ of RNA se was added and homogenized by inversion and incubated for 30 minutes at $37^{\circ} \mathrm{C}$. After this, the samples were incubated for 3 minutes on ice and $100 \mu 1$ of protein precipitation solution was added.

The tubes were vortexed for 20 seconds and then centrifuged for 5 minutes at 1,400 rpm. The supernatant was placed in a new tube, $300 \mu \mathrm{l}$ of isopropanol was added by inverting the remaining sample, the sequence another centrifugation at 1400 rpm for 5 minutes. The supernatant was discarded, and the tube was inverted and left to dryon absorbent paper. Subsequently, $70 \%$ alcohol was added to dry inverting it several times followed by centrifugation at $1400 \mathrm{rpm}$ for 5 minutes. The supernatant was discarded, and the tube was inverted and left to dryon absorbent paper. Finally, $25 \mu \mathrm{l}$ of ultrapure $\mathrm{H}_{2} 0$ was added for DNA hydration.

\subsection{PCR identification}

To determine the presence of parasites of the collected sand fly females, the extracted DNA samples were analyzed based on a PCR technique used for Leishmania ITS1 (Tail et al., 2000). For amplification, the pair of LITSR primers was used: 5 'CTGGATCATTTTCCGATG 3' and L5.8S: 5 'TGATACCACTTATCGCACTT 3'.

The reaction was prepared to a final volume of $25 \mu \mathrm{l}$ containing $5 \mu \mathrm{l}$ of the DNA sample, $2.5 \mu \mathrm{l}$ of $10 \mathrm{x}$ buffer solution, $0.75 \mu \mathrm{l} \mathrm{MgCl} 2(50 \mathrm{mM}), 0.5 \mu \mathrm{l}$ of $10 \mathrm{mM}$ dNTP mix, $1.25 \mu \mathrm{l}$ each of $10 \mu \mathrm{M}$ primers (LITSR and L5.8S), $0.25 \mu 1$ of $10 \mathrm{U} / \mu \mathrm{l} \mathrm{Taq}$ DNA polymerase, $1.25 \mu \mathrm{l}$ of dimethylsulfoxide and $12.25 \mu \mathrm{l}$ of sterile distilled water.

DNA amplification was conducted with an Eppendorf® Mastercycler Gradient automatic cycler using the following: initial denaturation for 2 minutes at $95^{\circ} \mathrm{C}$, sequencing 35 denaturation replicates for 30 seconds at $95^{\circ} \mathrm{C}$, annealing for 60 seconds at $53^{\circ} \mathrm{C}$ and extension for 60 seconds at $72^{\circ} \mathrm{C}$. The final extension was at $72^{\circ} \mathrm{C}$ for 10 minutes.

Twenty nanograms of DNA extracted from Leishmania braziliensis (MHOM / BR / 75 / M2903) was used as the positive control and sterile distilled water was used as the negative control. The results were observed on $2.0 \%$ agarose gel stained with ethidium bromide and viewed under ultraviolet (UV) light.

\subsection{Statistical analysis}

The following data were analyzed: richness, abundance, sex, infected females, and seasons of the year. Data meeting the prerequisite for normality were subjected to an analysis of variance (ANOVA). Tukey's post-hoc test was used when significant differences were detected $(\mathrm{p}<0.05)$. Non-parametric data were analyzed using the Kruskal-Wallis test by rank and median. A Mann-Whitney pairwise test was used when significant differences were detected ( $\mathrm{p}<0.05$ ) (Sokal \& Rohlf, 2011).The correlations between climatic variables (temperature and air humidity) and population density of Psychodidae were 
evaluated by means of Spearman's coefficient ( $\mathrm{p} \leq 0.05)$. All analyses were performed using the statistical software PAST v3.07 (Hammer et al., 2001).

\section{Results}

In our studies, from April 2015 to March 2016, it was possible to distinguish four seasons of the year, when 4,200 insects of family Psychodidae were collected, including two subfamilies: Sycoracinae and Phlebotominae. Subfamily Sycoracinae was represented by 4,193 specimens and subfamily Phlebotominae by 7 specimens of two species: Nyssomyia neivai (=Lutzomyia neivai) and Pintomyia fischeri (=Lutzomyia fischeri). The highest Psychodidae abundance was observed in Imaruí (57.2\%), followed by Criciúma (30.6\%) and Tubarão (12.2\%). An analysis of Psychodidae abundance revealed a significant difference between the number of specimens collected in the different cities $(F=27.1 ; p<0.05)$. Psychodidae abundance was significantly different between the three collection sites, considering the three cities $(\mathrm{F}=7.2 ; \mathrm{p}<0.05)$, with the highest abundance near feeding places for domestic animals (53.5\%). Subfamily Phlebotominae was registered in Imaruí and Tubarão (Table 2).

Table 2. Quantity of specimens of the family Psychodidae and subfamily Phlebotominae collected from April 2015 to March 2016, including sites and cities where the collections were made.

\begin{tabular}{|c|c|c|c|c|}
\hline \multirow[t]{2}{*}{ City } & \multirow[t]{2}{*}{ Collection Sites } & \multirow{2}{*}{$\begin{array}{c}\text { Family } \\
\text { Psychodidae } \\
\text { Abundance }\end{array}$} & \multicolumn{2}{|c|}{$\begin{array}{c}\text { Subfamily Phlebotominae } \\
\text { Abundance / Richness }\end{array}$} \\
\hline & & & Nyssomyia neivai & Pintomyia fischeri \\
\hline \multirow{3}{*}{ Criciúma } & Urban Forest & 406 & - & - \\
\hline & Animal Food Source & 809 & - & - \\
\hline & Peridomicile & 70 & - & - \\
\hline \multirow{3}{*}{ Imarui } & Urban Forest & 667 & - & - \\
\hline & Animal Food Source & 1.109 & - & - \\
\hline & Peridomicile & 627 & 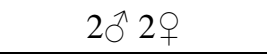 & $1 q$ \\
\hline \multirow{3}{*}{ Tubarão } & Urban Forest & 157 & $1 \lesssim 1$ 우 & - \\
\hline & Animal Food Source & 329 & - & - \\
\hline & Peridomicile & 26 & - & - \\
\hline
\end{tabular}

Source: Authors.

There was no significant difference in abundance between the different months, considering the three cities $(H=9.5 ; \mathrm{p}$ $>0.05)$. In order to find other factors relevant to the presence of phlebotomine in the cities, we categorized the seasons of the year and observed that the family Psychodidae was constantly reported in the collections; the data showed a greater number in autumn and lower number in winter (Figure 1). 
Research, Society and Development, v. 10, n. 14, e596101422480, 2021

(CC BY 4.0) | ISSN 2525-3409 | DOI: http://dx.doi.org/10.33448/rsd-v10i14.22480

Figure 1. Quantity of Psychodidae specimens in relation to the four seasons of the year.

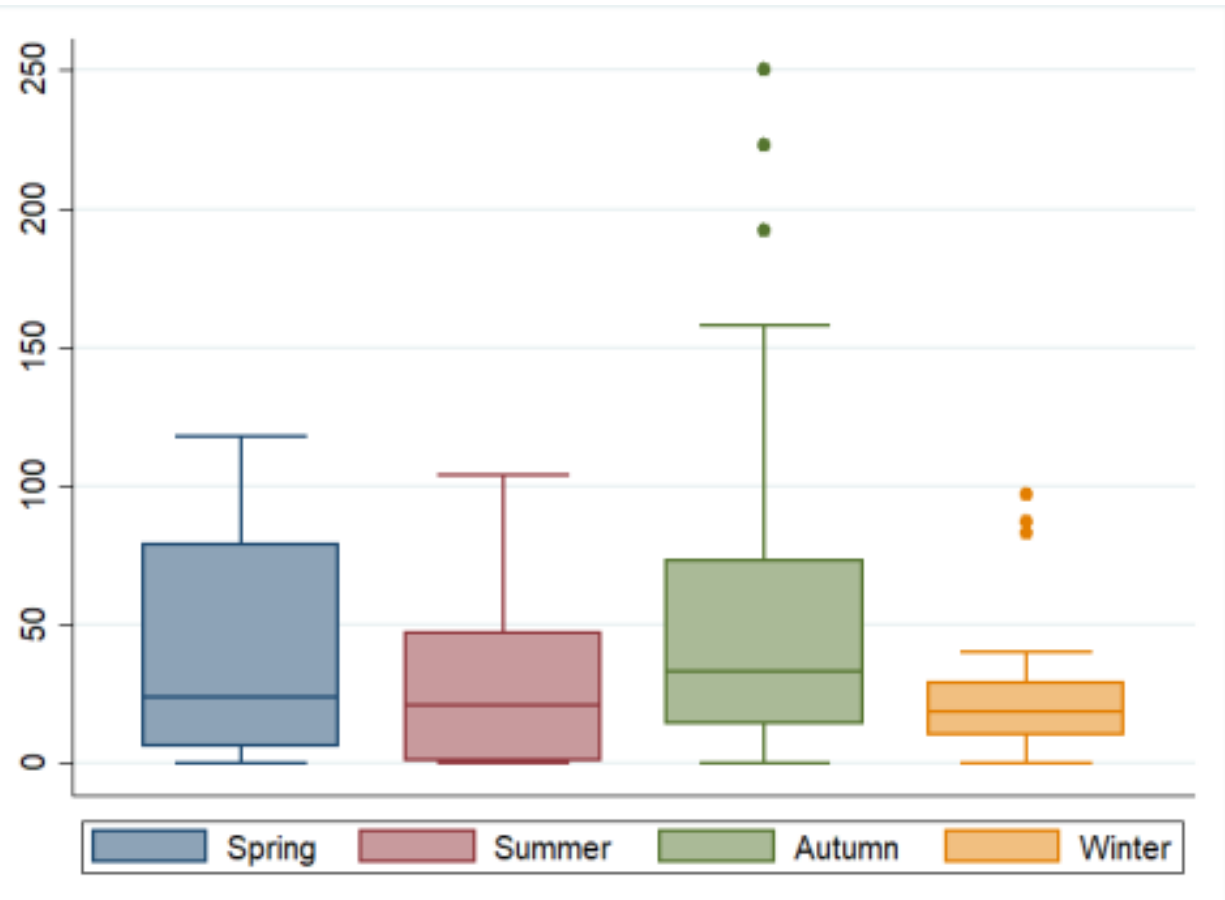

Source: Authors.

For sand fly, there were no specimens in winter. There was a significant difference in Psychodidae abundance between the seasons of the year $(\mathrm{F}=4.4 ; \mathrm{p}<0.05)$. The correlation between the number of Psychodidae captured and the climatic variables (temperature and relative air humidity), in each city, is shown in Figure 2. The climatic variables evaluated showed a positive Spearman correlation coefficient in relation to Psychodidae density, except for temperature in Tubarão. However, without significant differences (Figure 2). 
Figure 2. Correlation between population density of Psychodidae and climatic variables (temperature and relative humidity of the air) in three cities in Santa Catarina State, Brazil, from April 2015 to March 2016. a) Criciúma; Psychodidae vs. temperature (Spearman's rho $=0.34, \mathrm{n}=12, P=0.27$ ); Psychodidae vs. humidity (Spearman's rho $=0.18, \mathrm{n}=12, P=0.58$ ). b) Imaruí; Psychodidae vs. temperature (Spearman's rho =0.06, $\mathrm{n}=12, P=0.85$ ); Psychodidae vs. humidity (Spearman's rho $=0.04, \mathrm{n}=12, P=0.89$ ). c) Tubarão; Psychodidae vs. temperature (Spearman's rho $=-0.37, \mathrm{n}=12, P=0.23$ ); Psychodidae vs. humidity (Spearman's rho $=0.04, \mathrm{n}=12, P=0.89$ ).
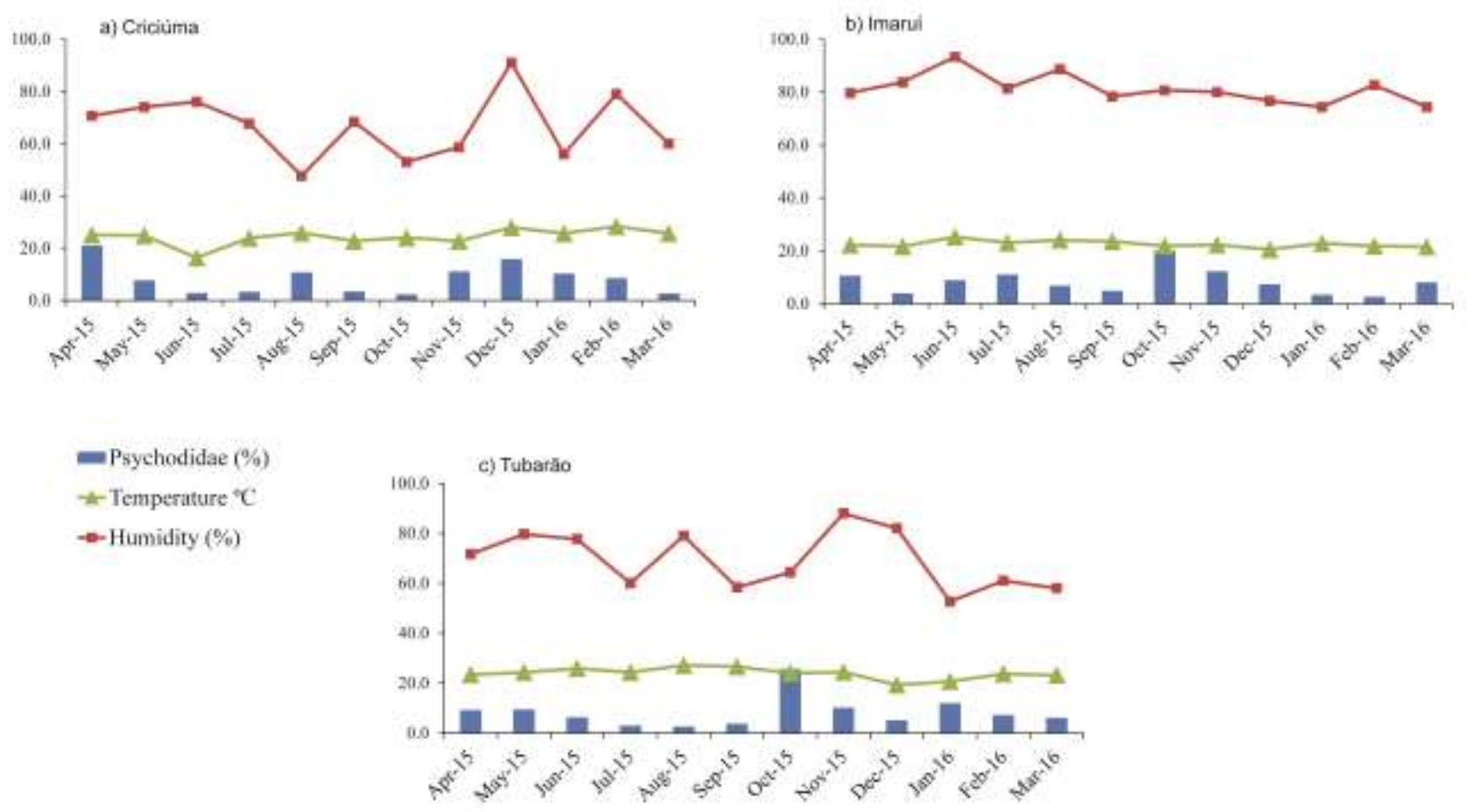

Source: Authors.

Finally, to verify the possible infection by Leishmania spp. in the sand fly females collected, molecular analysis techniques were used, which showed that all samples were negative for Leishmania spp. The results of the PCR technique used to investigate Leishmania infection in the sand flies collected were not positive for any of the analyzed samples.

\section{Discussion}

This study collected two subfamilies of Psychodidae: Sycoracinae and Phlebotominae. In a similar study in the city of Florianopolis, Santa Catarina State, 413 sand fly 658 were collected distributed in several species: Lutzomyia fischeri, Lu. Migonei, Lu. Neivai, Lu. edwardsi, Lu. tupynambai and Lu. firmatoi. Although the author did not provide details of the collection point characteristics, it can be inferred that the number of $L u$. neivai specimens collected was close to that obtained in our study because the author reported 10 females of this species; however, for Lu. fischeri the author reported 39 females (Dias et al., 2011).

In another study in Santa Catarina, in the city of Piçarras, Guimarães et al. (2014) (Guimarães et al., 2014) observed three species: Lu. neivai, Lu. fischeri and Lu. ayrozay. When comparing the similarity between the collection points and the 
number of individuals collected, these authors collected 4 Lu neivai in peridomicile area, while in the present study 2 males and 2 females were collected in a peridomicile area in Imaruí, as well as 1 male and 1 female in an urban forest in Tubarão. Beyond this point, the authors also observed a greater predominance of this species near residences. For Lu. fischeri, the authors reported the same number of individuals that were found in this study; for both studies, the presence of 1 female was observed for point near banana plants (Guimarães et al., 2014).

As found in the present study, for collections made in eastern Santa Catarina in 2000 (Marcondes et al., 2005), and in a study conducted in the northeast of state at 2008 (Grott et al., 2014), was observed Nyssomyia neivai as a predominant phlebotomine species. Similar results were also obtained in a study conducted during 2012 in Paraná State (dos Santos et al., 2016). This species of phlebotomine is often found in peridomiciliary regions (dos Santos et al., 2016; Grott et al., 2014; Marcondes et al., 2005).

Pintomyia fischeri has been recorded in the states of the South Region of Brazil and is essentially a wild species, although it has already been found in peridomestic rural habitats (Pita-Pereira et al., 2011). Although only one specimen of this species was collected in the present work, the habitat characteristics that Pita-Pereira et al. (2011) (Pita-Pereira et al., 2011) correlate with encountering P. fischeri correspond to the similarity of the collection point where the species was found. Considering the abundance of $P$. fischeri in deforested areas, it can be suggested that this species is well suited to live in the surroundings of forests and environments with anthropic changes (Pita-Pereira et al., 2011).

The geographic distribution of Psychodidae species can be influenced by physical barriers, rainfall, vegetation, luminosity and abundance of vertebrate hosts (Aguiar et al., 1985). It is also known that the presence of animals influences the density of sand flies near human dwellings and, consequently, increases the transmission risk of Leishmania species to humans (Arias et al., 1985; Lainson et al., 1983; Rangel \& Lainson, 2009).

Individuals of family Psychodidae were collected in peridomicile, urban forest and animal feeding source areas; a greater quantity was collected in the city of Imaruí, followed by the cities of Criciúma and Tubarão. For subfamily Phlebotominae the records were from the cities of Imaruí and Tubarão. The greater number of individuals for both Psychodidae and Phlebotominae in Imaruí is probably related to the fact that this city has a large amount of vegetation, even in places near the peridomicile area. In Tubarão, the sand fly specimens were found in a region near urban forest, thus corroborating authors who noted that the majority of phlebotomine species are essentially wild, although they have been found in rural peridomestic habitats (Feitosa \& Castellón, 2006; Guimarães et al., 2014; Marlow et al., 2013).

When the collection points were compared, we found a predominance of individuals close to the animal food source, possibly due to the diversity of ecotypes that comprise the sites selected as an animal food source and to the eclectic habits of the captured species, since in these areas there are domestic animals such as dogs, birds, pigs and cattle. On the other hand, the peridomiciliary environment has more human interference, which probably hinders the adaptation of some species of sand flies (Rêgo et al., 2014; Ximenes et al., 1999). It is important to mention that the peridomicile areas of the houses studied have mostly rural characteristics with the presence of domestic animals and plantations of fruit trees and grains that provide an environment with refuges and food for sand flies and the organic matter necessary for the development of immature forms of these insects. This may explain the occurrence of sand fly records in these areas, even in low numbers.

In Paraná State, researchers evaluated the seasonality of phlebotomines and demonstrated that in hot and humid seasons of the year these insects are captured in greater numbers (Teodoro et al., 1993, 2001). The fact that southern Santa Catarina State has few sand flies may explain the low number of leishmaniasis cases, since this disease is not endemic to this region, although we know that there is a serious problem of unreported cases (Gontijo \& Melo, 2004). Thus, constant monitoring of 
circulating species is important since, when an increase of species or specimens is recorded over years, control methods must be considered that can prevent this disease from becoming endemic to southern Santa Catarina.

All sand fly samples that were subjected to molecular analysis had negative results, which is probably related to the low number of samples. Another factor that contributes to the lack of protozoan detection is that in non-endemic areas the circulation of this protozoan is low. Dias et al. (2010) (Dias et al., 2011) evaluated the natural infection of sand flies by Leishmania spp. in the city of Florianopolis, using the SSUrRNA PCR technique, and obtained 658 specimens of sand fliesof the following species: Lutzomyia fischeri, L. migonei, L. edwardsi, L. tupynambai, L. firmatoi and L. neivai. However, of the 136 "pools" per species of sand fly captured, only 9 pools were positive for Leishmania spp..

Therefore, should be taken into account that the epidemiology of leishmaniasis is conditioned the presence of vectors (phlebotomines) that can transmit the etiological agent Leishmania spp. and the presence of wild and synanthropic mammalian hosts and/or reservoirs (Souza et al., 2010). The great diversity of vectors, reservoirs and agents influence changes in the epidemiological patterns of leishmaniasis, and the influence of humans on the environment also makes it difficult to control the disease (de Brito et al., 2014).

\section{Conclusion}

Clinical, biological and epidemiological characterization studies are fundamental to the development of individualized action and prevention strategies, since transmission patterns, vector species, leishmaniasis species, and response to treatment can be very different in some regions. Thus, it is important that we better understand which species are circulating in our study area. The present study updated and expanded the knowledge of the geographic distribution of leishmaniasis vectors, which may assist both in the acquisition of knowledge about the behavior of species, as well as in the strategies of surveillance and control of this disease. The areas without confirmed records, but suitable for the occurrence of the species, should be verified in future studies of survey of phlebotomine fauna. We suggest that the monitoring of these species to be accomplished out periodically in other municipalities in the south of Santa Catarina in addition to those highlighted in this study so that you can have an overview of the recurrent species and make a comparison with those that have already been listed for the state.

\section{References}

Aguiar, G. M. de, Schuback, P. D., Vilela, M. L., \& Azevedo, A. C. R. (1985). Aspectos da ecologia dos flebótomos do Parque Nacional da Serra dos Orgãos, Rio de Janeiro: II. Distribuição vertical (Diptera, Psychodidae, Phlebotominae). Memórias Do Instituto Oswaldo Cruz, 80(2), 187-194. https://doi.org/http://dx.doi.org/10.1590/S0074-02761985000200009

Alvar, J., Vélez, I. D., Bern, C., Herrero, M., Desjeux, P., Cano, J., Jannin, J., \& de Boer, M. (2012). Leishmaniasis worldwide and global estimates of its incidence. PLOS ONE, 7(5). https://doi.org/10.1371/journal.pone.0035671

Alves, W. A. (2009). Leishmaniose visceral americana: situação atual no Brasil. Boletim Epidemiológico Paulista, 6(71), 25-29.

Arias, J. R., Miles, M. A., Naiff, R. D., Povoa, M. M., de Freitas, R. A., Biancardi, C. B., \& Castellon, E. G. (1985). Flagellate infections of Brazilian sandflies (Diptera: Psychodidae): Isolation in vitro and biochemical identification of Endotrypanum and Leishmania. American Journal of Tropical Medicine and Hygiene, 34(6), 1098-1108. https://doi.org/10.4269/ajtmh.1985.34.1098

Bejarano, E. E., \& Estrada, L. G. (2016). Family psychodidae. Zootaxa, 4122(1), 187-238. https://doi.org/10.11646/zootaxa.4122.1.20

Brito, V. N., de Almeida, A. do B. P. F., Nakazato, L., Duarte, R., Souza, C. de O., \& Sousa, V. R. F. (2014). Phlebotomine fauna, Natural infection rate and feeding habits of Lutzomyia cruzi in Jaciara, State of Mato Grosso, Brazil. Memorias Do Instituto Oswaldo Cruz, 109(7), 899-904. https://doi.org/10.1590/0074-0276140112

Deboni, S., Barbosa, M., \& Ramos, R. (2011). Leishmaniose Visceral no Rio Grande do Sul. Boletim Epidemiológico, 13(1), 1-3. http://www1.saude.rs.gov.br/dados/1326723576051v.13, n.1, mar., 2011.pdf

Dias, E. S., Monteiro, É. M., Lopes, J. V., \& Ferreira, E. de C. (2011). Detecção de infecção por Leishmania spp. em flebotomíneos coletados na cidade de Florianópolis (SC) - Relatório Técnico-Científico Final. In Comitê Gestor de Recursos Laboratoriais. http://www.pmf.sc.gov.br/arquivos/arquivos/pdf/29_12_2010_11.23.25.da431176e5d86a0650f1cc57ffbf749b.pdf 
dos Santos, B. A., Reinhold-Castro, K. R., Cristóvão, E. C., Silveira, T. G. V., \& Teodoro, U. (2016). Sand flies on Paraná River Islands and natural infection of Nyssomyia neivai by Leishmania in southern Brazil. Journal of Vector Ecology, 41(1), 186-189. https://doi.org/10.1111/jvec.12211

Feitosa, M. A. C., \& Castellón, E. G. (2006). Fauna de flebotomíneos (Diptera: Psychodidae) em fragmentos de floresta ao redor de conjuntos habitacionais na cidade de Manaus, Amazonas, Brasil. I. Estratificação vertical. Acta Amazonica, 36(4), 539-548. https://doi.org/10.1590/S0044-59672006000400016

Figueiredo, F. B., Júnior, F. E. F. de L. J., Tomio, J. E., Indá, M. C., Corrêa, G. L. B., \& Madeira, M. de F. (2012). Leishmaniose Visceral Canina : Dois casos autóctones no município de Florianópolis , estado de Santa Catarina. Acta Scientiae Veterinariae, 40(1), 4-7.

Galati, E. A. B. (2003). Morfologia e taxonomia: classificaçao de phlebotominae. In E. F. Rangel \& R. Lainson (Eds.), Flebotomíneos do Brasil (Fiocruz, pp. 23-51).

Gontijo, C. M. F., \& Melo, M. N. (2004). Leishmaniose visceral no Brasil: quadro atual, desafios e perspectivas. Revista Brasileira de Epidemiologia, 7(3), 338-349. https://doi.org/10.1590/s1415-790x2004000300011

Grott, S. C., Greinert-Goulart, J. A., Rodrigues, C. M., Steindel, M., Schaefer, M., \& Marcondes, C. B. (2014). Epidemiologia E Distribuição De Flebotomíneos (Díptera: Phlebotominae) Em Áreas De Transmissão Da Leishmaniose Tegumentar Americana - Blumenau-Sc, Brasil. Revista de Patologia Tropical, 43(4), 483-491. https://doi.org/10.5216/rpt.v43i4.33616

Guimarães, V. C. F. V., Costa, P. L., da Silva, F. J., de Melo, F. L., Dantas-Torres, F., Rodrigues, E. H. G., \& Brandão-Filho, S. P. (2014). Detecção molecular de Leishmania spp. em flebotomíneos em area endêmica para leishmaniose tegumentar e visceral no nordeste do Brasil. Revista Do Instituto de Medicina Tropical de Sao Paulo, 56(4), 357-360. https://doi.org/10.1590/S0036-46652014000400015

Hammer, Ø., Harper, D. A. T., \& Ryan, P. D. (2001). PAST: Paleontological statistics software package for education and data analysis. https://palaeoelectronica.org/2001_1/past/issue1_01.htm

Lainson, R., Shaw, J. J., Silveira, F. T., \& Frahia, H. (1983). Leishmaniasis in Brazil. XIX: Visceral leishmaniasis in the Amazon Region, and the presence of Lutzomyia longipalpis on the Island of Marajó, Para State. Transactions of the Royal Society of Tropical Medicine and Hygiene, 77(3), 323-330.

Marcondes, C. B., Conceição, M. B. E., Portes, M. G. T., \& Simão, B. P. (2005). Phlebotomine sandflies in a focus of dermal leishmaniasis in the eastern region of the Brazilian State of Santa Catarina - Preliminary results (Diptera: Psychodidae). Revista Da Sociedade Brasileira de Medicina Tropical, 38(4), 353-355. https://doi.org/10.1590/S0037-86822005000400016

Marlow, M. A., da Silva Mattos, M., Makowiecky, M. E., Eger, I., Rossetto, A. L., Grisard, E. C., \& Steindel, M. (2013). Divergent Profile of Emerging Cutaneous Leishmaniasis in Subtropical Brazil: New Endemic Areas in the Southern Frontier. PLoS ONE, 8(2). https://doi.org/10.1371/journal.pone.0056177

Ministério da Saúde. (2020a). LEISHMANIOSE TEGUMENTAR AMERICANA - Casos confirmados Notificados no Sistema de Informação de Agravos de Notificação - Brasil. Sistema de Informação de Agravos de Notificação - Sinan Net. http://tabnet.datasus.gov.br/cgi/tabcgi.exe?sinannet/cnv/ltabr.def

Ministério da Saúde. (2020b). LEISHMANIOSE TEGUMENTAR AMERICANA - Casos confirmados Notificados no Sistema de Informação de Agravos de Notificação - Santa Catarina. Sistema de Informação de Agravos de Notificação - Sinan Net. http://tabnet.datasus.gov.br/cgi/tabcgi.exe?sinannet/cnv/ltasc.def

Ministério da Saúde. (2020c). LEISHMANIOSE VISCERAL - Casos confirmados Notificados no Sistema de Informação de Agravos de Notificação - Brasil. Sistema de Informação de Agravos de Notificação - Sinan Net. http://tabnet.datasus.gov.br/cgi/tabcgi.exe?sinannet/cnv/leishvbr.def

Ministério da Saúde. (2020d). LEISHMANIOSE VISCERAL - Casos confirmados Notificados no Sistema de Informação de Agravos de Notificação - Santa Catarina. Sistema de Informação de Agravos de Notificação - Sinan Net. http://tabnet.datasus.gov.br/cgi/tabcgi.exe?sinannet/cnv/leishvsc.def

Pape, T., Blagoderov, V., \& Mostovski, M. B. (2011). Order Diptera Linnaeus, 1758. In Z.-Q. ZHANG (Ed.), Animal biodiversity: an outline of higher-level classification and survey of taxonomic richness. Zootaxa, Vol. 3148, pp. 222-229). http://www.mapress.com/zootaxa/2011/f/zt03148p229.pdf

Pita-Pereira, D. de, Souza, G. D., Pereira, T. de A., Zwetsch, A., Britto, C., \& Rangel, E. F. (2011). Lutzomyia (Pintomyia) fischeri (Diptera: Psychodidae: Phlebotominae), a probable vector of American Cutaneous Leishmaniasis: Detection of natural infection by Leishmania (Viannia) DNA in specimens from the municipality of Porto Alegre (RS), Brazil, using . Acta Tropica, 120(3), 273-275. https://doi.org/10.1016/j.actatropica.2011.09.004

Quaresma, P. F., Rêgo, F. D., Botelho, H. A., da Silva, S. R., Moura, A. J., Neto, R. G. T., Madeira, F. M., Carvalho, M. B., Paglia, A. P., Melo, M. N., \& Gontijo, C. M. F. F. (2011). Wild, synanthropic and domestic hosts of Leishmania in an endemic area of cutaneous leishmaniasis in Minas Gerais State, Brazil. Transactions of the Royal Society of Tropical Medicine and Hygiene, 105(10), 579-585. https://doi.org/10.1016/j.trstmh.2011.07.005

Ramos, W. R., Medeiros, J. F., Julião, G. R., Ríos-Velásquez, C. M., Marialva, E. F., Desmouliére, S. J. M., Luz, S. L. B., \& Pessoa, F. A. C. (2014). Anthropic effects on sand fly (Diptera: Psychodidae) abundance and diversity in an Amazonian rural settlement, Brazil. Acta Tropica, 139, 44-52. https://doi.org/10.1016/j.actatropica.2014.06.017

Rangel, E. F., \& Lainson, R. (2009). Proven and putative vectors of American cutaneous leishmaniasis in Brazil: Aspects of their biology and vectorial competence. Memorias Do Instituto Oswaldo Cruz, 104(7), 937-954. https://doi.org/10.1590/S0074-02762009000700001

Rêgo, F. D., Shimabukuro, P. H. F., Quaresma, P. F., Coelho, I. R., Tonelli, G. B., Silva, K. M. S., Barata, R. A., Dias, E. S., \& Gontijo, C. M. F. (2014). Ecological aspects of the Phlebotominae fauna (Diptera: Psychodidae) in the Xakriabá Indigenous Reserve, Brazil. Parasites and Vectors, 7(1), 1-12. https://doi.org/10.1186/1756-3305-7-220

Sherlock, Í. A. (2003). Importância dos flebotomíneos. In E F Rangel \& R. Lainson (Eds.), Flebotomíneos do Brasil (Fiocroz, pp. 15-22).

Sokal, R. R., \& Rohlf, F. J. (2011). Biometry: the principles and practice of statistics in biological research (W. H. F. \& Company (ed.); 4th ed.).

Souza, A. A. A., Silveira, F. T., Lainson, R., Barata, I. R., Silva, M. G. S., Lima, J. A. N., Pinheiro, M. S. B., Silva, F. M. M., Vasconcelos, L. S., Campos, M. B., \& Ishikawa, E. A. Y. (2010). The Phlebotominae fauna of Serra dos Carajás, Pará, Brazil, and its possible implication in the transmission of American 
Research, Society and Development, v. 10, n. 14, e596101422480, 2021

(CC BY 4.0) | ISSN 2525-3409 | DOI: http://dx.doi.org/10.33448/rsd-v10i14.22480

tegumentary leishmaniasis. Revista Pan-Amazônica de Saúde, 1(1), 81-86. https://doi.org/10.5123/S2176-62232010000

Tail, N. El, Osman, F., Far, M. El, Presbefi, W., \& Schiinian, G. (2000). Genetic heterogeneity of ribosomal internal transcribed spacer in clinical samples of Leishmania donovani spotted on filter paper as revealed by single-strand conformation polymorphisms and sequencing. Transactions of the Royal Society of Tropical Medicine and Hygiene, 94, 575-579.

Teodoro, U., La Salvia Filho, V., de Lima, E. M., Spinosa, R. P., Barbosa, O. C., Ferreira, M. E., \& Lonardoni, M. V. (1993). Phlebotomine behavior in forest and extraforest environments, in an endemic area of American cutaneous leishmaniasis in northern Paraná State, southern Brazil. Revista de Saúde Pública, 27(4), 242-249. https://doi.org/10.1590/s0034-89101993000400003

Teodoro, U., Silveira, T. G. V, Santos, D. R., Santos, E. S., Santos, a R., Oliveira, O., \& Kühl, J. B. (2001). Freqüência da fauna de flebotomíneos no domicílio e em abrigos de animais domésticos no peridomicílio, nos municípios de Cianorte e Doutor Camargo - estado do Paraná -. Brasil. Rev Patol Trop, 30(2), 209-233.

World Health Organization. (2010). Control of the leishmaniases. World Health Organization Technical Report Series, 949, $22-26$.

Ximenes, M. D. F. F. de M., De Souza, M. D. F., \& Castellón, E. G. (1999). Density of Sand Flies (Diptera: Psychodidae) in Domestic and Wild Animal Shelters in an Area of Visceral Leishmaniasis in the State of Rio Grande do Norte, Brazil. Memorias Do Instituto Oswaldo Cruz, 94(4), 427-432. https://doi.org/10.1590/s0074-02761999000400001

Young, D. G., \& Duncan, M. A. (1994). Guide to the identification and geographic distribution of Lutzomyia sand flies in mexico, the west indies, central and south america (diptera: psychodidae) (Issue 54). 